\title{
The Fortieth Anniversary of Larry P. V. Riles: Cognitive Assessment and Black Children
}

\author{
Isaac L. Woods Jr ${ }^{1} \cdot$ Scott L. Graves Jr ${ }^{2}$ \\ Published online: 5 May 2021 \\ (C) California Association of School Psychologists 2021
}

Arguably the most well-known legal decision related to cognitive assessment was the Larry P. v. Riles case. The call for this special issue section came out exactly 40 years after the decision by Judge Robert Peckham in 1979. The legacy of Judge Peckham's legal decision and merits of the comments throughout testimony has contributed to research and practice of assessing Black children.

\section{Origins of Larry P. V. Riles Case}

During a meeting in San Francisco for the American Psychological Association (APA), more than 200 Black psychologists charged APA with failing to condone racism and recognize the emerging Black movement as a model for solving problems stemming from oppressive effects of American racism (Williams, 2008). Specifically, a petition of concerns was submitted at the inception of the Association of Black Psychologists to APA with the inappropriate use of psychological tests to maintain and justify the practice of systematically denying educational and economic opportunities to Black youth as a primary concern of the petition (Williams, 1974). Approximately 3 years later, the NAACP (National Association for the Advancement of Colored People) Legal Defense fund filed a suit on behalf of the parents of six African-American elementary school children in the US District Court of the

Isaac L. Woods, Jr

isaac.woods@uky.edu

Scott L. Graves, Jr

graves.388@osu.edu

1 Department of Educational, School, and Counseling Psychology, College of Education, University of Kentucky, Lexington, KY, USA

2 School Psychology, Department of Educational Studies, The Ohio State University, Columbus, OH, USA
Northern District of California (Larry P. v. Riles, 1979). In June 1972, Judge Robert Peckham issued a preliminary injunction against the San Francisco Unified School District (SFUSD) requiring the use of IQ tests that do not take into account the cultural and spiritual background of Black children and on December 1974 extended the injunction to include all Black children in the state of California who were inappropriately misclassified as EMR (Thomas, 2020). The trial included notable Black psychologists such as Drs. Harold Dent, Reginald Jones, Asa Hillard, William Pierce, and Gerald West and testimony from one of the most well-known psychologists and test developers David Wechsler. An excerpt from Judge Peckham's decision (Larry P. v. Riles, 1979):

Dr. David Wechsler in 1944 stated this problem quite strongly in his introduction to the WISC, which he developed:

[W]e have eliminated the colored vs. white factor by admitting at the outset that our norms cannot be used for the colored population of the United States. Though we have tested a large number of colored persons, our standardization is based upon white subjects only. We omitted the colored population from our first standardization because we did not feel that norms derived by mixing the population could be interpreted without special provisos and reservations.

Wechsler's observations apply with equal force to the other standardized tests. The tests were standardized and developed on an all-white population, and naturally, their scientific validity is questionable for culturally different groups (p. 957).

Although ignored at the inception of cognitive tests development by David Wechsler, multiple articles in this special issue attempt to understand the scientific validity of cognitive assessments for Black children. Of equal concern in this special issue topic section is the training, applications, and lasting impact of the Larry P v. Riles case. 


\section{Overview of Special Issue Section}

Although this case was decided 40 years ago, the implications are still felt today. For instance, in August of 2020, KALW Public Radio published a story titled: A Legacy of Mistreatment For San Francisco's Black Special Ed Students (Romney, 2020). Larry P, whose real name is Darryl Lester, was interviewed for the story and he indicated that he struggled with reading and he did not receive any help while being placed in special education. As such, this special issue on the Larry P. case is timely.

The first article, by Dr. Aston and Dr. Brown, examines current practices, perceptions, and application of culturally biased tests for Black students. This study surveys school psychologists on issues related to culturally appropriate assessments, validity of cognitive tests to measure IQ, and culturally biased tests as a factor for the disproportionality in special education. Implications from this investigation provide insight on the utilization of culturally sensitive assessment practices. In the second article, Dr. Miller and colleagues examine the state of cognitive assessment training by conducting a national review of graduate program course syllabi. The next article by Dr. Graves and colleagues explored the factor structure of the most commonly used cognitive assessment instrument, the Wechsler Intelligence Scale for Children-Fifth edition (WISC-V). This study provides evidence that the WISC-V may not measure the same constructs for Black and White students. Relatedly, in the fourth article, Dr. Smith and Dr. Graves examine the gender invariance of the WISC-V among Black students in an urban sample. Their findings indicate that scores are not interpretable at the same level for the Verbal Comprehension and Working Memory indexes between Black boys and girls. While Graves and colleagues (2021) and Smith and colleagues (2021) focus on the construct validity of a popular intelligence test, Dr. Woods and colleagues examined the predictive validity of Cattell-Horn-Carroll (CHC) theory for Black students using the Woodcock-Johnson IV Tests of Cognitive Abilities (WJ IV). There is no evidence that CHC theory's broad abilities can predict reading skills for Black students due to poor model fit. The next article, by Dr. Powers, investigates how due process cases involving a dispute between a family and a local education agency have been interpreted by the Office of Administrative Hearings in the state of California. Themes and trends from complaints are presented and recommendations to correct institutional injustices that exacerbate the disproportionality of Black students in special education. The final article by Dr. Gamble and Dr. Hiramoto provides a perspective on the Larry P. case by a former California Association of School Psychology (CASP) President and a former CASP Board Member. This perspective is important given that the Larry P. case is specific to the state of California.
In sum, the studies in this special issue have the potential to advance best practices in training and service delivery for children in schools. The research provided also reveals several issues with the current state of training and practice as it relates to cognitive assessment. While programs still cling to decades' old practices in their training, practitioners' views of the field are markedly different from their program training. This is vital because the use of intelligence tests for placement decisions is problematic given that special education services are not effective for improving outcomes (Graves \& Ye, 2017; Morgan et al., 2010; Sullivan \& Field, 2013). The editors hope the information presented within this special issue will compel readers to evaluate their practices as it relates to utilizing intelligence tests and their results with Black children.

\section{Declarations}

Human and Animal Rights Research involving human participants and/ or animals

No human participants and/or animals were involved.

Informed consent Not applicable.

Conflict of interest The authors declare no competing interests.

\section{References}

Graves, S. L., \& Ye, F. F. (2017). Are special education labels accurate for Black children? Racial differences in academic trajectories of youth diagnosed with specific learning and intellectual disabilities. Journal of Black Psychology, 43(2), 192-213. https://doi.org/10. 1177/0095798416636280.

Larry P. v. Riles, 495 F. Supp. 926 (United States District Court, N.D. California October 16, 1979). https://law.justia.com/cases/federal/ district-courts/FSupp/495/926/2007878/.

Morgan, P. L., Frisco, M. L., Farkas, G., \& Hibel, J. (2010). A propensity score matching analysis of the effects of special education services. The Journal of Special Education, 43(4), 236-254. https://doi.org/ 10.1177/0022466908323007.

Romney, L. (2020, August 10). A legacy of mistreatment for San Francisco's Black special Ed students. KALW Local Public Radio. https://www.kalw.org/post/legacy-mistreatment-sanfrancisco-s-black-special-ed-students\#stream/0.

Sullivan, A. L., \& Field, S. (2013). Do preschool special education services make a difference in kindergarten reading and mathematics skills?: A propensity score weighting analysis. Journal of School Psychology, 51(2), 243-260. https://doi.org/10.1016/j.jsp.2012.12.004.

Thomas, W. (2020). Larry P. Revisited: IQ testing of African Americans: Learning while Black (2nd ed.). Newman Springs Publishing, Inc

Williams, R. (1974). A history of the Association of Black Psychologists: Early formation and development. Journal of Black Psychology, l(1), 9-24. https://doi.org/10.1177/2F009579847400100102.

Williams, R. L. (2008). A 40-year history of the Association of Black Psychologists (ABPsi). Journal of Black Psychology, 34(3), 249 260. https://doi.org/10.1177/2F0095798408321332. 
Publisher's Note Springer Nature remains neutral with regard to jurisdictional claims in published maps and institutional affiliations.

Dr. Isaac Woods Jr. (He/Him/His) is an Assistant Professor in the Department of Educational, School, and Counseling Psychology at the University of Kentucky.
Dr. Scott L. Graves Jr. is an Associate Professor and the Director of the Positive Youth Development Lab (PYDL) at The Ohio State University. His research agenda is focused on identifying strengths in African American children that lead to positive social-emotional and academic outcomes. 